\title{
THE EFFECT OF STUDENT TEAM ACHIEVEMENT DIVISION COOPERATIVE LEARNING (STAD CL) IN TEACHING THE READING COMPREHENSION
}

\author{
Ahmad Nur Syafiq $^{1}{ }^{\bowtie}$, Amalia Rahmawati ${ }^{2}$ \\ Prodi Keperawatan Fakultas Keperawatan \\ Stikes Muhammadiyah Kudus, Indonesia
}

\section{Info Artikel}

SejarahArtikel:

Diterima Februari 2017

Disetujui Mei 2017

Dipublikasikan Juni 2017

\section{Keywords:}

STAD, Cooperative

Learning and reading comprehension skill

\begin{abstract}
Abstrak
Penelitian ini bertujuan untuk mengetahui pengaruh Student Team Achievement Division Cooperative Learning (STAD CL)pada siswa kelas XI SMA 1 Kudus dan menemukan solusi dan strategi untuk membuat para mengaplikasikannya dalam menyampaikan materi pelajaran menjadi lebih efektif. Penelitian ini merupakan penelitian eksperimental. Populasi penelitian ini adalah siswa kelas XI SMA 1 Kudus di Tahun Akademik 2015/2016. Ada lima kelas dari XI-A sampai XI -E. Setiap kelas memiliki 35 siswa, sehingga total populasi adalah 175 siswa. Sedangkan sampel penelitian ini adalah delapan puluh siswa dari empat kelas yang dipilih berdasarkan faktor historis dan kemampuan yang sudah ada sebelumnya. 80 siswa dipilih menjadi sampel, 40 kelompok eksperimen dan 40 kelompok kontrol. Kedua kelompok diberi pre-test untuk mengukur kemampuan membaca siswa dan setelah beberapa kali perlakuan, kedua kelompok diberi posttest.Hasil penelitian menunjukkan bahwa terdapat perbedaan yang signifikan antara kelompok eksperimen dan kelompok kontrol terhadap prestasi membaca. Oleh karena itu, STAD CL lebih efektif daripada konvensional, karena kebanyakan siswa mengalami peningkatan dalam membaca mereka di kelas. Studi lebih lanjut juga dapat dilakukan untuk mengetahui apakah penggunaan STAD CL oleh guru dapat mengurangi kecemasan dan stres siswa di kelas untuk meningkatkan kemampuan membaca siswa atau bahkan keterampilan, retensi, dan hubungan siswa dengan guru.
\end{abstract}

\begin{abstract}
This study aims at investigating the effects of Student Team Achievement Division Cooperative Learning (STAD CL) at eleventh grade students of Senior High School 1 Kudus and finding solutions and strategies to make teachers have a formed opinion of the use of STAD in delivering the subject matter while teaching to make more it effective.This study was experimental research. The population of this study was the eleventh year students of Senior High School 1 Kudus in the Academic Year 2015/2016. There were five classes from XI-A to XI -E. Each class had 35 students, so the total population were 175 students. Meanwhile the samples of this study were eighty students from four classes which were selected based on the historical factors and preexisting ability. 80 students were choosen to be a sample, 40 as experimental group and 40 as control group. Both groups were given the pre-test to measure students' reading skill and after several times of treatments, both groups were given the post-test.The results of the study showed that there was significant difference between the means of experimental and control groups on the reading achievement. Hence, STAD CL was more effective than conventional in the way that mostly students developed their reading performance in the classroom. Further study may also be conducted to determine whether teachers' use of STAD CL appears to reduce student anxiety and stress in the classroom to improve students' reading or even other skills, retention, and studentteacher relationships.
\end{abstract}

(C) 2017 UniversitasMuria Kudus
p-ISSN 2087-9385

e-ISSN 2528-696X
Program StudiPendidikan Guru SekolahDasar

FakultasKeguruandanIlmuPendidikanUniversitasMuria Kudus

Kampus UMK Gondangmanis, Bae Kudus Gd. L. 1t I PO. BOX 53

Kudus

Tlp (0291) 438229 ex.147 Fax. (0291) 437198

E-mail: ahmadnursvafia@stikesmuhkudus.ac.id 


\section{INTRODUCTION}

Reading is one of the basic communicative skills, but it has a very complex process of learning. Reading can be said as an interactive process because reading needs a reader to guess, predict, check, and ask questions about what the text is about. Reading has two purposes that are: reading for general ideas and reading to locate specific information (Wiratno, 2002: 163). Moreover, reading is a complex process, which involves not only the readers ability to read the text but also their ability to comprehend it. Because of this reason, many teachers of English at junior high and senior high school find difficulties in teaching reading. Most of the Indonesians students do not really understand what they have read, even though they have been learning reading.

The importance of reading can be seen from the fact that the main part of the national examination in senior high schools was to do with reading skills. It has been stated by one of the teachers of Senior High School 1 Kudus that various questions on the English national exam are intended to assess students' reading comprehension. One of reasons students got bad mark of English examination is because they are still lack of reading skill. Therefore they could not finish answering reading questions.

Teaching reading comprehension levels with some strategies or skills is quite demanding for English teachers because many learners face difficulty in understanding textbooks in English Fitrawati (2009). Although comprehension can be taught directly its teaching requires teachers to be well-informed, creative, and innovative about theories, approaches, methods, models, media (Depdiknas, 2007). On the top of that, the teachers are required to have opportunities to experiment the various approaches, models or methods (Arends and Kilcher, 2010).

One of the models to teach reading are Cooperative learning (CL). As it is stated by Wichadee (2006) that cooperative learning method can increase students' reading comprehension skill. CL in this term refers to the use of Student Teams-Achievement Division (STAD). According to Slavin, (2009), STAD consists of five major components: class presentation,teams, quizzes, individual improvement scores, and team recognition. In STAD (Slavin: 2009, students are assigned to four-member learning teams that are mixed in performance level, gender, and ethnicity. The teacher presents a lesson, and then students work within their teams to make sure that all team members have mastered the lesson.
Therefore, this study attempts to investigate the effects of STAD CL on improving students' reading comprehension at eleventh grade students of Senior High School 1 Kudus. Further, the study also attempts to find solutions and strategies to make teachers have a formed opinion of the use of STAD CL in delivering the subject matter while teaching to make more it effective.

\section{RESEARCH METHODOLOGY}

This study is kind of experimental research design. Experimental research is the way to find the causal relationship between two factors, which are raised by the researcher. In doing an experimental research, usually two groups are involved and compared to find the influence of a treatment. As cited in Marczky (2005:3)

The population of this study was the eleventh year students of Senior High School 1 Kudus in the Academic Year 2015/2016. There were five classes from XI-A to XI - E. Each class had 35 students, so the total population were 175 students. Meanwhile the samples of this study were 80 students in the way that the groups which was taken for the research was class X1- A to X1- C consisting of 40 students as Experimental group and class $\mathrm{X} 1-\mathrm{C}$ to $\mathrm{X} 1-\mathrm{E}$ consisting of 40 students as Control group. Both groups were selected based on the historical factors and pre-existing ability.

There were two variables included in this study.The dependent variable (Y) is the students' reading comprehension skill and the independent variable $(\mathrm{X})$ is STAD CL and DI as teaching methods in teaching reading.

ANATES and SPSS software were utilized to analyze the result of the pre test and the posttest in the way thet ANATES could automatically analyze the reliability, the level of difficulty, discrimination index and distracters' quality of the items. It helped researcher to identify the quality of the test items quickly and appropriately. The second one, SPSS could easily analyze quantitative data just by following the procedures.

The total scores obtained from ANATES were then statistically analyzed through the SPSS software. Before having ANOVA, the data were tested using normality and homogenity. The normality was used to check whether the distribution of score each group in pre-test and posttest was normal or not. If the distribution score was normal, it can be said that the distribution of the test was valid. The testing of normality was carried by using Shapiro-Wilk and Kolmogorov-Smirnov test. Meanwhile the 
homogenity is to know whether both of groups were from homogeneous population or not. The test was needed to decide whether the sample was from the same population. To do the homogeneous variants test of the population, It was done by holding Lavene Statistic Test. Then lastly analyzing the data into ANOVA, This analysis was intended to see which teaching program STAD CL or DI is more effective in improving the students 'comprehension in general. Thus, To test the hypotheses, Two-way analysis of variance with F-test at the 5\% (0.05) level of significance was used. It is to answer the problem that claimed whether there is any effect of the use of STAD CL and DI model development of students' reading skill.

\section{RESULT AND DISCUSSION}

PRE TEST RESULT OF EXPERIMENTAL AND CONDTROL GROUP

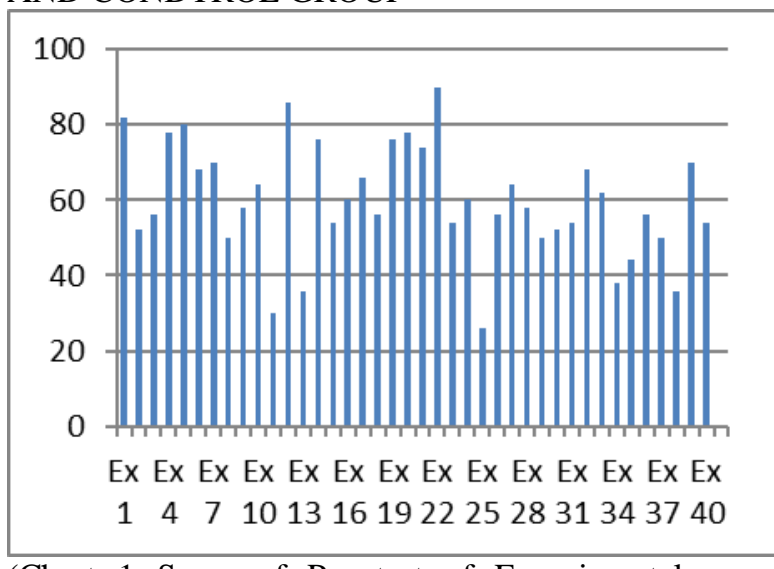

(Chart 1 Score of Pre test of Experimental Group)

It can be seen from the chart that The lowest score from experimental group was 26 and the highest score was 90 .

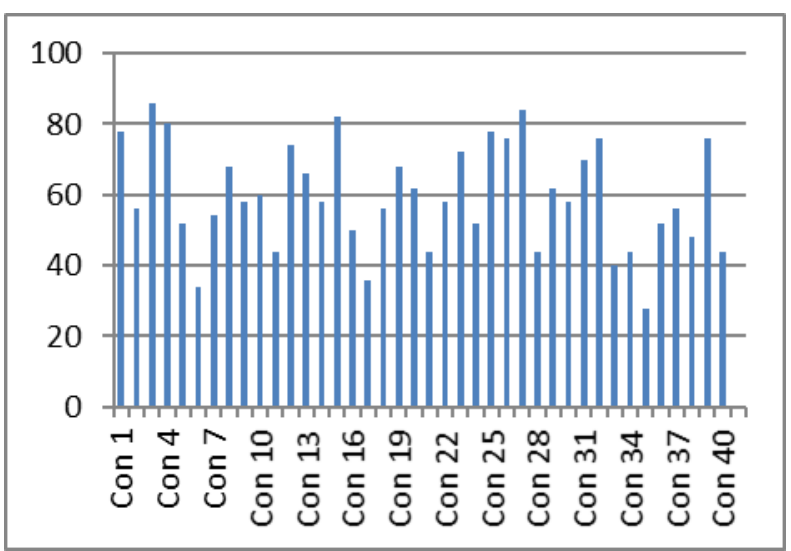

Group)
It can be seen from the chart the lowest score from control group was 28 and the highest score was 86. Pre-test score had purpose to measure the students' ability in reading comprehension before treatment.

POST TEST RESULT OF EXPERIMENTAL AND CONDTROL GROUP

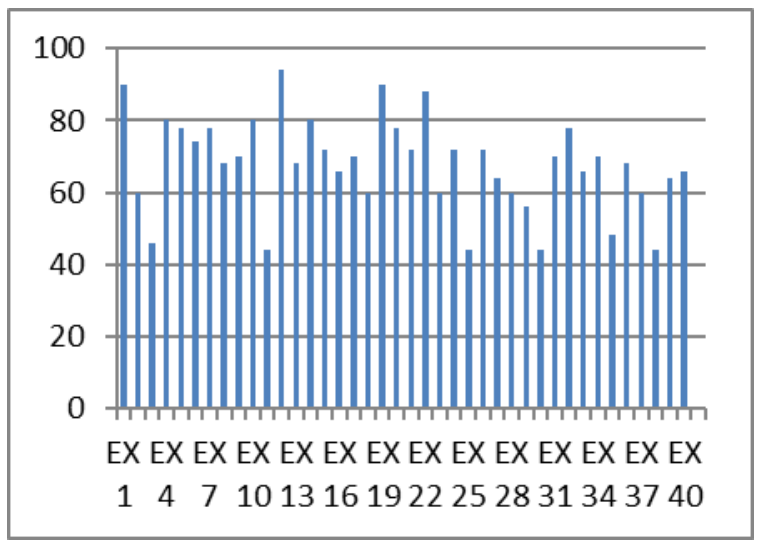

(Chart 3 Score of Post test of Experimental Group)

The result of improving students' reading achievement using STAD CL model very high in the way that the highest score was 94 and the lowest score was 44 .

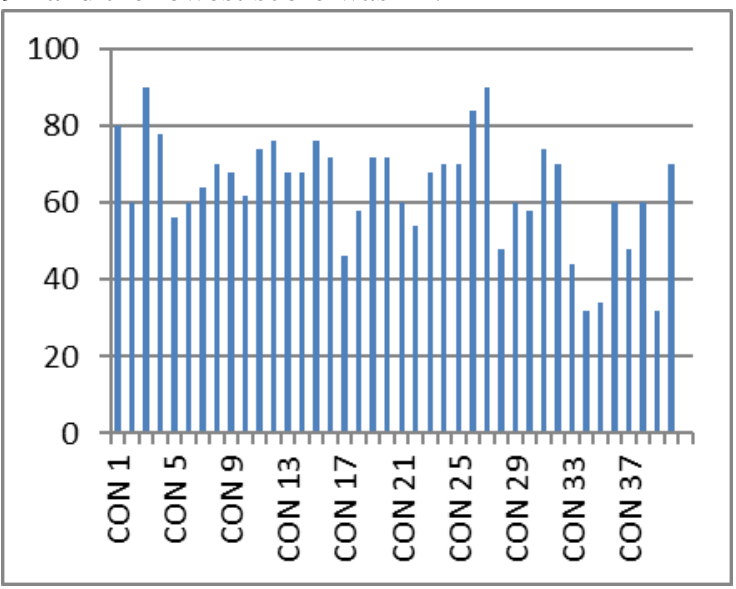

\section{(Chart 4 Score of Post test of Control}

Group)

The result of improving students' reading achievement using conventional model was not as high as experimental group. It was seen from the highest score was 90 and the lowest score was 26 .

There was a significant difference between experimental and control group taught by STAD CL and conventional technique in reading comprehension of the eleventh year students of Senior High School 1 Kudus in the academic year 2015/2016. The summary of means' score is presented in the following table: 
(table 1.1 comparison of mean score between pre and post test)

\begin{tabular}{|l|l|l|l|l|l|l|}
\hline & \multicolumn{2}{|l|}{ pre } & \multicolumn{2}{l|}{ post } & \multicolumn{2}{l|}{ range } \\
\hline & Ex & Co & Ex & Co & Ex & Co \\
\hline $\mathrm{M}$ & 59.8 & 59.6 & 67.8 & 63.9 & $=8$ & $\begin{array}{l}= \\
7.3\end{array}$ \\
\hline Hi & 90 & 86 & 94 & 90 & & \\
\hline Lo & 26 & 28 & 44 & 32 & & \\
\hline
\end{tabular}

Note:

Ex: Experimental group

Co: Control group

$\mathrm{M}$ : Mean

Hi: Highest Score

Lo : Lowest Score

The data of pre and post test described that the average achievement in pre test was still very low thus it indicates that the students still get difficulties to understand reading comprehension. Meanwhile in post test the average achievement increases thus it indicates that the treatments of both group are success but the use of STAD CL has better improvement than conventional model. Below is the table of post test achievement using STAD CL.

Later on, the result of students' reading competence by STAD CL teaching model of the eleventh year students of Senior High School 1 Kudus was very high. It means that STAD CL makes students get better achievement in reading skill. Moreover, the average score of both groups is statistically difference in the progress in the way that mean of STAD CL group achievement is higher that mean of convensional teaching model therefore the use of STAD CL teaching model English reading classroom in improving their reading skill is effective rather than conventional method.

In STAD CL group the process of teaching learning activity was running well in the way that students performed the presentation in their small group and it was effective to make them focus and pay attention to the lesson. Moreover, the use of STAD CL model in teaching reading was good and appropriate either motivating them to be active in class presentation or encouraging them to be confidence in the class in the way that students work together in achieving its goals by presenting their own matrial in the group, help and motivate students to succeed shared passion, active role as a peer tutor to further enhance the success of the group, and doing interaction among students with increasing their ability to argue. In addition, their reading competence improved naturally with the various ways of learning.

Tests of Between-Subjects Effects

Dependent Variable: Post Test Score
\begin{tabular}{|l|r|r|r|r|r|} 
Source & $\begin{array}{c}\text { Type III Sum } \\
\text { of Squares }\end{array}$ & df & Mean Square & \multicolumn{1}{c|}{ F } & \multicolumn{1}{c|}{ Sig. } \\
\hline Corrected Model & $304,200^{\mathrm{a}}$ & 1 & 304,200 & 1,655 &, 202 \\
Intercept & 346897,800 & 1 & 346897,800 & 1887,682 &, 000 \\
STADCLdanDI & 304,200 & 1 & 304,200 & 1,655 &, 202 \\
Error & 14334,000 & 78 & 183,769 & & \\
Total & 361536,000 & 80 & & & \\
Corrected Total & 14638,200 & 79 & & & \\
\hline
\end{tabular}
a. R Squared $=, 021$ (Adjusted R Squared $=, 008$ )

From the hypothesis testing showed that STAD CL teaching has a significant influence the learning achievement of reading comprehension which is proven by $\mathrm{F}$ value $>\mathrm{F}$ table meaning that STAD CL teaching model has significant effect on the achievement of reading comprehension.

Those result above later on indicates that five procedures of STAD CL used by the teacher is very efficient and interesting. For example, in the class presentation in the way that students should perform one by one, students pay attention more to the class. Based on the results of the achievement, despite the students in the school are very heterogeneous in their levels of reading skill, it is found this technique to be a good alternative solution in teaching reading class with mixed level of achievements because they have a good chance of learning from each other especially in developing their vocabulary.

Meanwhile in conventional class, the class runs quite monotone because the method only follows a step-by-step procedure. The procedure usually starts with an introduction, followed by the rationale for the instruction, then by the instruction itself. The procedure ends with a summary and then followed by an assessment. Moreover, in direct teaching, if the teacher is not well prepared, he ot she may difficult to runs the class because he or she must have a mastery of the subject matter, must prepare a well-organized content, and must have excellent communication skills. Without these traits, a teacher could not effectively carry out direct teaching or direct instruction, nor could they develop higher order thinking skills in the students.

In short, STAD CL teaching model has better significant improvement for the students' reading skill rather than conventional teaching model. The result is in line with study conducted by Osborne (2003) which states that cooperative learning is one of teaching strategies which improves the academic achievement of ESL students. It was proven by different range of pre and post test of both 
groups. Some students reported that STAD CL strategy in the classroom situation affected their learning positively to those who have high low motivation rather than conventional.

\section{CONCLUSSION}

It can be concluded that the result of improving students' reading competence by STAD CL teaching model was very high. It means that, STAD CL supported students to have better achievement in reading comprehension. Thus, STAD CL as teaching model for teaching reading is more effective than conventional model in the way that students are able to increase their reading performance in the classroom and reduce barriers between them and their teachers.

These findings can have implications not only for teachers and learners, but also for syllabus designers and material developers. It is hoped that the study will be helpful to English teachers to better understand how STAD be used successfully in foreign language learning classes. Teachers should give time to students in order to make them interact with their peers in the groups in class than make students only do the activities in student textbooks.

\section{REFERENCES}
Alderson, J.C. 2000. Assessing Reading.Cambridge: Cambridge University Press.

Arends, R.I and Kilcher, A. 2010. Teaching for Students'Learning. New York: Routledge.
Depdiknas. 2007. Permendiknas No.41 Tahun 2007 tentang Standar Proses. Jakarta: Depdiknas.

Fitrawati. (2009). Improving Senior High School Students' Reading Comprehension through Reading Strategies Derived from Genre Based Approach. JurnalBahasadanSenivol 10 no. 2, p 89-99, ejournal.unp.ac.id [9 October, 2012].

Marczky, Geoffrey R.2005. Essentials of Research Design and Methodology. New Jersey: John Wiley \& Sons, Inc.

Osborne, A. (2003) Examining the Effects of the Tribes TLC Process on Cooperative Learning and Students' Positive Interaction in Language Minority Classrooms. (A Journal), http: gse.gmu.edu. [9 October, 2012].

Slavin, Robert E. (2009). Cooperative Learning (theory, Research and Practice). Bandung: Nusa Media.

Wichadee, S. 2006. The Effects of Cooperative Learning on English Reading Skills and Attitudes of the First-Year Students at Bangkok University (A Journal), http://www.bu..pdf [9 October, 2012].

Wiratno, Tri. 2002. Mencerna Buku Text Bahasa Inggris Melalui Pemahaman Gramatika. Yogyakarta. Pustaka Pelajar. 